Ryszard Mielimąka

ORCID: 0000-0002-0815-7737

Henryk Kleta

ORCID: 0000-0003-3521-6605

\title{
PROSPECTS OF MINING OPERATIONS IN SHAFT PROTECTION PILLARS \\ IN TERMS OF THE ASSESSMENT METHOD OF STRAIN EFFICIENCY OF THEIR LINING AND CALCULATIONS OF ROCK MASS DEFORMATION
}

\author{
Faculty of Mining, Safety Engineering and Industrial Automation \\ Silesian University of Technology in Gliwice
}

Keywords: mine shafts, deformation surveys, stability of lining

\begin{abstract}
The assessment involving the prospects of mining exploitation, in particular with the disruption of protective pillars, is frequently a fundamental issue in the engineering practice. It is even more important when the problem involves the completed mining exploitation which was carried out for many years and which already brought about stress-strain changes in the protected objects whose technical condition should ensure safety of use.

The impact of mining exploitation on rock mass and surface ground can be most reliably determined basing on the results of geodetic surveys, but in practice, in the conditions where mining exploitation was carried out for many years, the results of geodetic surveys with the records of deformations that occurred in such areas are not available. Then, to assess the impact of mining operations carried out so far, we can only apply the available partial results of geodetic surveys. It happens in situations when we are to assess the prospects of mining exploitation, especially with the disruption of the protective pillar of mining shafts, which are of fundamental importance for mining operations.

The article presents an exemplary assessment involving the prospects of mining exploitation with roof fall in the protective pillar of shafts in terms of the results of the reprognosis involving the impact of completed mining exploitation on the surface ground and rock mass.

The methodology used to assess the prospects of further mining exploitation in the vicinity of the protective pillar of main shafts takes into account the fact that in view of the reprognosis results, years-long mining exploitation carried out to the boundaries of the protective pillar resulted in relatively large horizontal displacements around the area of the shafts, and smaller vertical displacements. In such circumstances, the latest surveys of horizontal displacements were used to infer about the current curvature of the vertical axis of shaft No.1, located closest to the plots of the completed mining. The calculation involving the possibility to carry out further mining operations within the impact range on the protected shafts No.1 and No.2 was determined by comparing the calculated permissible curvature radius of the shaft axis, reflecting the strain efficiency of the lining, with the calculated curvature radius of the vertical axis of the shaft lining effected by horizontal displacements of rock mass.
\end{abstract}




\title{
MOŻLIWOŚĆ EKSPLOATACJI GÓRNICZEJ W FILARZE OCHRONNYM SZYBÓW W ŚWIETLE SPOSOBU OCENY ZDOLNOŚCI ODKSZTALCENIOWEJ ICH OBUDOWY I OBLICZEŃ DEFORMACJI GÓROTWORU
}

Słowa kluczowe: szyby górnicze, pomiary deformacji, stateczność obudowy

\begin{abstract}
Abstrakt
Ocena możliwości prowadzenia eksploatacji górniczej, szczególnie z naruszeniem filarów ochronnych, stanowi często podstawowe zagadnienie w praktyce inżynierskiej. Szczególne znaczenie tego zagadnienia występuje w przypadku dokonanej wieloletniej eksploatacji górniczej, która już spowodowała zmiany naprężeniowo-odkształceniowe w chronionych obiektach, a których stan techniczny powinien zapewnić bezpieczeństwo użytkowania.

Wpływ eksploatacji górniczej na górotwór i powierzchnię terenu najbardziej wiarygodnie można określić na podstawie wyników pomiarów geodezyjnych, jednakże w praktyce w warunkach, gdy eksploatacja górnicza była prowadzona przez wiele lat, brak jest wyników pomiarów geodezyjnych, które rejestrowały zachodzące deformacje w takim rejonie. Wówczas dla potrzeb oceny wpływu dotychczasowej eksploatacji górniczej pozostaje tylko możliwość wykorzystania dostępnych cząstkowych wyników pomiarów geodezyjnych. Taka sytuacja występuje przy ocenie możliwości prowadzenia eksploatacji górniczej szczególnie z naruszeniem filara ochronnego dla szybów górniczych, które posiadają podstawowe znaczenie dla działalności górniczej.

W artykule przedstawiono przykładową ocenę możliwości prowadzenia eksploatacji górniczej z zawałem stropu w filarze ochronnym dla szybów w świetle wyników reprognozy dotychczasowych wpływów eksploatacji górniczej na powierzchnię terenu i górotwór.

W zastosowanej metodyce oceny możliwości prowadzenia dalszej eksploatacji górniczej w rejonie filara ochronnego szybów głównych uwzględniono, że w świetle wyników wykonanej reprognozy, wieloletnia eksploatacja górnicza prowadzona do granic filara ochronnego spowodowała w miejscu szybów stosunkowo duże przemieszczenia poziome, przy jednocześnie mniejszych przemieszczeniach pionowych. Stan taki pozwolił na skorzystanie z ostatnich pomiarów przemieszczeń poziomych umożliwiających wnioskowanie o aktualnej krzywiźnie osi pionowej szybu nr 1, położonego najbliżej parcel dokonanej eksploatacji górniczej. Obliczeniowo ocenę możliwości prowadzenia dalszej eksploatacji górniczej w zasięgu oddziaływania na chronione szyby $\mathrm{nr} 1 \mathrm{i} \mathrm{nr}$, określono porównując obliczony dopuszczalny promień krzywizny osi szybu, wynikający ze zdolności odkształceniowej obudowy z obliczonym promieniem krzywizny osi pionowej obudowy szybu spowodowanej poziomymi przemieszczeniami górotworu.
\end{abstract}

\section{INTRODUCTION}

With respect to mining exploitation carried out within the area of impact exerted on surface or underground objects, their safe operation is dependent, above all, on their technical condition and the extent and history of the impact exerted by the completed mining exploitation. The article presents an exemplary assessment involving the possibility of conducting mining operations with roof fall in the protective pillar of the main coal mine plant in terms of the carried out reprognosis of the past impact of mining operations on surface ground and on the protected main shafts. The presented methodology of conduct regarding the possibility to carry out further mining operations was based on the authors' yearslong experience in issuing expert opinions on mining exploitation plans of mine plants. The presented assessment involving the prospects of mining exploitation with roof fall in the protective pillar was conditioned by the protection of main shafts, taking into account the assessment method of strain efficiency of their lining and the current technical condition of the shafts.

\section{BASIC ASSUMPTIONS INVOLVING THE ASSESSMENT OF THE PROSPECTS OF MINING EXPLOITATION IN THE PROTECTION PILLAR OF SHAFTS}

The assessment involving the prospects of mining exploitation, particularly with the disruption of protective pillar, should allow for a number of issues whereof examination determines warranted decisions to undertake further mining exploitation having impact on the objects protected by the pillar. With respect to mining shafts, which are of fundamental importance for mining 
operations in underground mines, the following issues should be taken into account $[2,7,9]$ :

- current technical condition of the shaft, particularly with regard to its technical characteristics, type and structural design of the lining, including its strength,

- mining and geological as well as hydrogeological conditions,

- results of surface ground deformation surveys along with surveys and observations in the shaft,

- resistance of the protected objects together with the determination of strain efficiency of the shaft lining.

The strain efficiency of the shaft lining is based on the assumption that the relation between rock mass deformations and the structural or material strain efficiency of the lining is a measure of the occurrence of its damage [5].

To determine the strain efficiency of the shaft lining, and thus to assess the possibility of the impact being taken on by the lining, the following factors should be considered as most important $[3,4,5,7,8]$ :

- horizontal strains of the rock mass and lining,

- vertical strains of the rock mass and lining,

- curvature radius of the bent shaft lining.

The impact of mining exploitation on rock mass and on surface ground can be most reliably determined, e.g. basing on the results of geodetic surveys. Particularly complicated is the case when the intensity of mining exploitation is high, and the exploitation period lasts several dozen years $[6,8,10]$. Such areas where regular observations and surveys were being carried out do not exist in practice, and hence the only possibility left is to use the available partial results of geodetic surveys.

\section{GEOLOGICAL AND}

HYDROGEOLOGICAL CONDITIONS IN THE EXEMPLARY AREA ALONG WITH THE CHARACTERISTICS OF THE TECHNICAL CONDITION AND STRENGTH OF SHAFT LINING

The following formations can be distinguished in the profile of the examined shafts (No. 1 and No. 2):

- Quaternary (up to a depth of approx. $20 \mathrm{~m}$ ),

- Tertiary (from a depth of $20 \mathrm{~m}$ to approx. $502 \mathrm{~m}$ )

- Carboniferous (from approx. $502 \mathrm{~m}$ ).
Quaternary formations are made of layers of clay, silts and dusty sands, and in the Tertiary formations, silts and sandy silts dominate.

Carboniferous formations are represented by claystones and mudstones, sandstones and coal seams.

The Quaternary formation consists of river sediments, postglacial and Aeolian sediments of the thickness of about $20 \mathrm{~m}$ to $22 \mathrm{~m}$. The layers of Quaternary gravel are formed as ground water reservoirs. The inflow ranges from 2 to $20 \mathrm{dm}^{3} / \mathrm{min}$., and is found at the depth of approx. $20 \mathrm{~m}$ and $21.5 \mathrm{~m}$; the volume of inflow depends on the level of groundwater.

The Tertiary formation consists of Miocene clays and sand with dusty sand. As the depth increases (from about $350 \mathrm{~m}$ ), the frequency of sandy layers is rising.

At the depth of about 320 to $380 \mathrm{~m}$, there is the so-called "Upper Miocene horizon", consisting of sandy sediments. At the depth of about 410 to 490 meters below the surface, we have the "Lower Miocene horizon" - a water and gas collector consisting of layers of marl, dusty sandstone, sand and sandstone. During the sinking of the examined shafts, water inflow of up to $50 \mathrm{dm}^{3} / \mathrm{min}$ was recorded on that horizon, along with a small outflow of methane.

In the bed of Miocene sediment, on the Carboniferous relief, there are layers called "detritus horizon", from 2 to $3 \mathrm{~m}$ thick, within which there were large water inflows during the sinking of shafts.

Shaft No.1 performs the function of an intake-air shaft, it has the inner lining diameter of $7.50 \mathrm{~m}$, and the total depth of the shaft is $1104.0 \mathrm{~m}$. Shaft No. 1 has a brickwork lining from the near-surface edge of shaft lining to the depth of $30 \mathrm{~m}$, and below, the final lining is made of C20/25-class concrete.

Shaft No. 2 has the function of an upcast ventilation shaft, with the inner lining diameter of $7.50 \mathrm{~m}$ and the depth of about $1000 \mathrm{~m}$. Shaft No. 2 has a brickwork lining from the near-surface shaft lining edge to the depth of $28 \mathrm{~m}$, and below the depth of $310 \mathrm{~m}$, the inner layer of lining is made of concrete, and the outer layer is made of brickwork. From the depth of $310 \mathrm{~m}$ to the depth of $534 \mathrm{~m}$, the shaft has a single-layer brickwork lining. Below the depth of $534 \mathrm{~m}$ to the sump, the shaft lining is made of monolithic concrete.

The carried out macroscopic evaluation of the lining of main shafts demonstrates that for the shaft No.1 the lining has only surface corrosion defects, up to several centimeters deep, and occasionally larger defects, up to 
$10 \mathrm{~cm}$ deep. There were no cracks, concrete loosening or deformations that could be critical for the stability of the shaft lining throughout the entire lining section. For the technical condition of the lining of shaft No.1, for individual characteristic sections of the lining, the adopted assessment can be from satisfactory to good.

In the case of shaft No.2, during the inspection of lining condition, no cracking or corrosion was observed. The technical condition of the shaft lining can be assessed as good.

Shaft 1 and shaft 2 were sunk in the 1960s. Due to close proximity of the shafts, very similar geolog- ical and hydrogeological conditions, the same type of applied lining and its good technical condition, the strength properties of the final lining of the shafts can be assessed on the basis of tests carried out for shaft No.1 only. The sclerometric tests of the lining of shaft No. 1 demonstrate that the brickwork lining has an average strength of $10 \mathrm{MPa}$ at the depth of $450 \mathrm{~m}$ to $36 \mathrm{MPa}$ at the depth of $24 \mathrm{~m}$. A relatively large dispersion of the obtained survey results is effected by the moisture content in the tested material and the presence of impurities covering the lining. And the characteristic strength of concrete obtained from the tests is $8.59 \mathrm{MPa}$, and

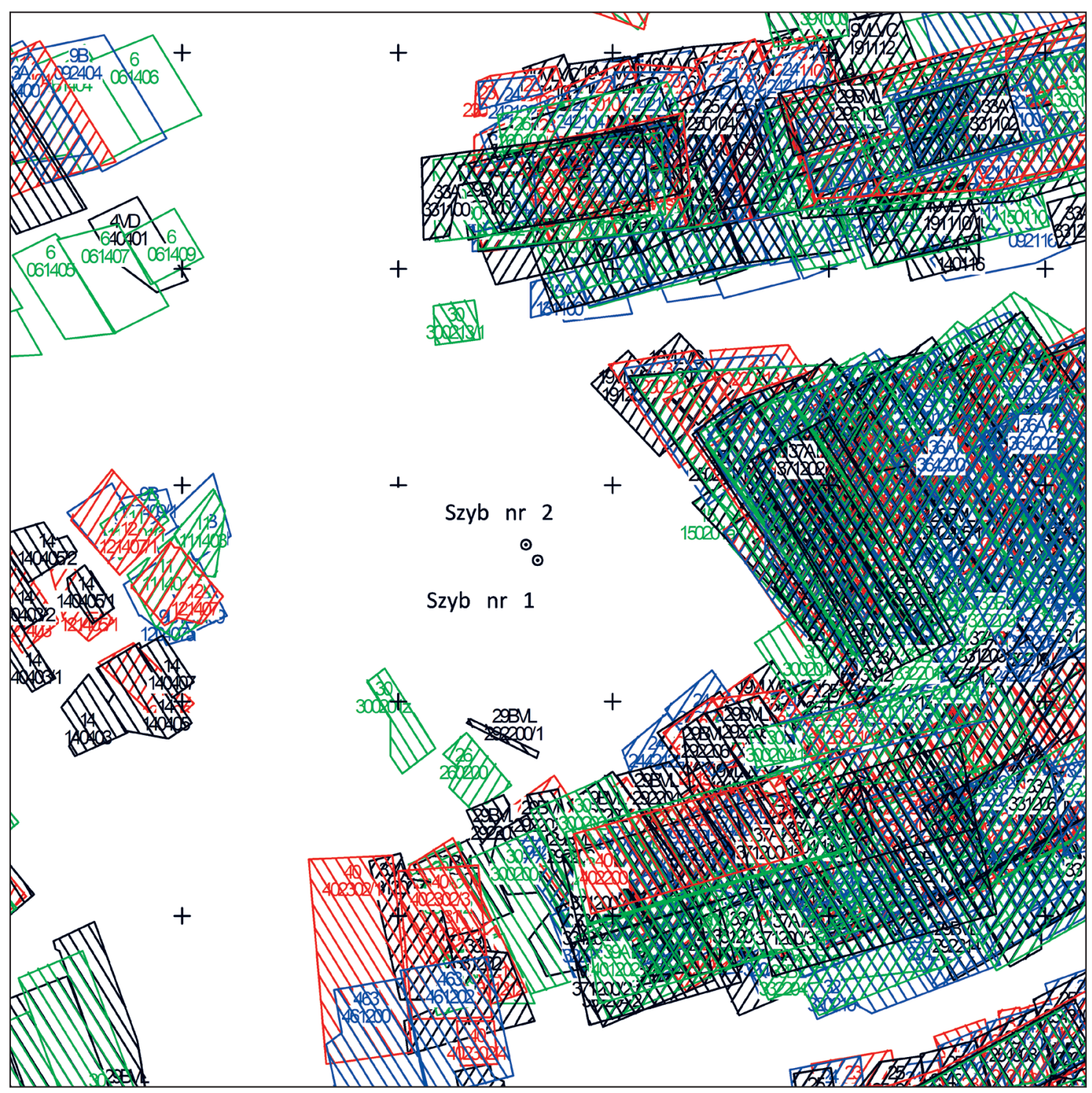

Fig. 1. Location of the contours of completed mining plots in relation to the location of shafts No.1 and No.2 Rys. 1. Położenie konturów parcel eksploatacji dokonanej w stosunku do usytuowania szybów nr 1 i nr 2 
when we allow for the safety factor, its design strength is $5.73 \mathrm{MPa}$. The obtained test results confirm good technical condition of the lining of shafts and the lack of strength decline of the lining.

\section{IMPACT OF PAST MINING OPERATIONS ON THE EXAMINED SHAFTS IN TERMS OF SURVEYS AND CALCULATIONS}

In the period covering the years 1968-2018, the Coal Mine " $X$ " carried out intensive mining operations altogether in 30 seams. In total, 700 longwall excavations were selected, with the mining depth ranging from $490 \mathrm{~m}$ to approx. $1180 \mathrm{~m}$. Mining was carried out with a transverse and longitudinal roof fall longwall system.

Fig. 1 presents the contours of the mined out longwall workings in relation to the location of shafts 1 and 2 .

The actual state of rock mass or shaft deformation is always best characterized by systematic geodetic surveys, including the surveys of horizontal displacements (shaft deflection from vertical direction). Due to the lack of systematic leveling measurements in the investigated area, it was assumed that the impact of mining operations on the main shafts can be assessed basing on the measurement results of horizontal displacements in shaft No.1. The results of such measurements may define the current deflection of the shaft from the vertical direction, effected by the impact of completed mining.
To date, the mining plant performed two survey cycles in shaft No. 1, the first in September 2018 and the next in March 2019. The measured resultant horizontal displacements at individual measuring points (1-9) in shaft No.1 demonstrate that the maximum horizontal displacements can be estimated at approx. $841 \mathrm{~mm}$ (Figs. 2, 3).

The measurements of horizontal displacements in shaft No. 1 (Fig. 2, 3) indicate the displacement of rock masses towards the resultant "center" of the completed multi-seam mining.

The assessment of the remaining deformation indicators in the examined shafts is possible only through the reprognosis of the deformations at the place of shafts No.1 and No.2, which was performed with the programs EDBJ (EDBJ1 and EDBJ2) using the basic formulas of W.Budryk-S.Knothe theory [1]. In the calculations, we used the parameters of the theory determined on the basis of horizontal displacements measured in shaft No.1 on the horizons located along the shaft tube (Fig. 2). The deformations of rock mass at the places of main shafts No. 1 and No. 2 were calculated at the points located every $20 \mathrm{~m}$ in the shafts starting from the ordinate of the near-surface edge of shaft lining. For each point, the final, maximum and minimum values of basic deformation indices effected by the completed mining were determined, i.e. the values of subsidence, horizontal displacements, inclinations, horizontal strains, main horizontal strains, vertical strains.

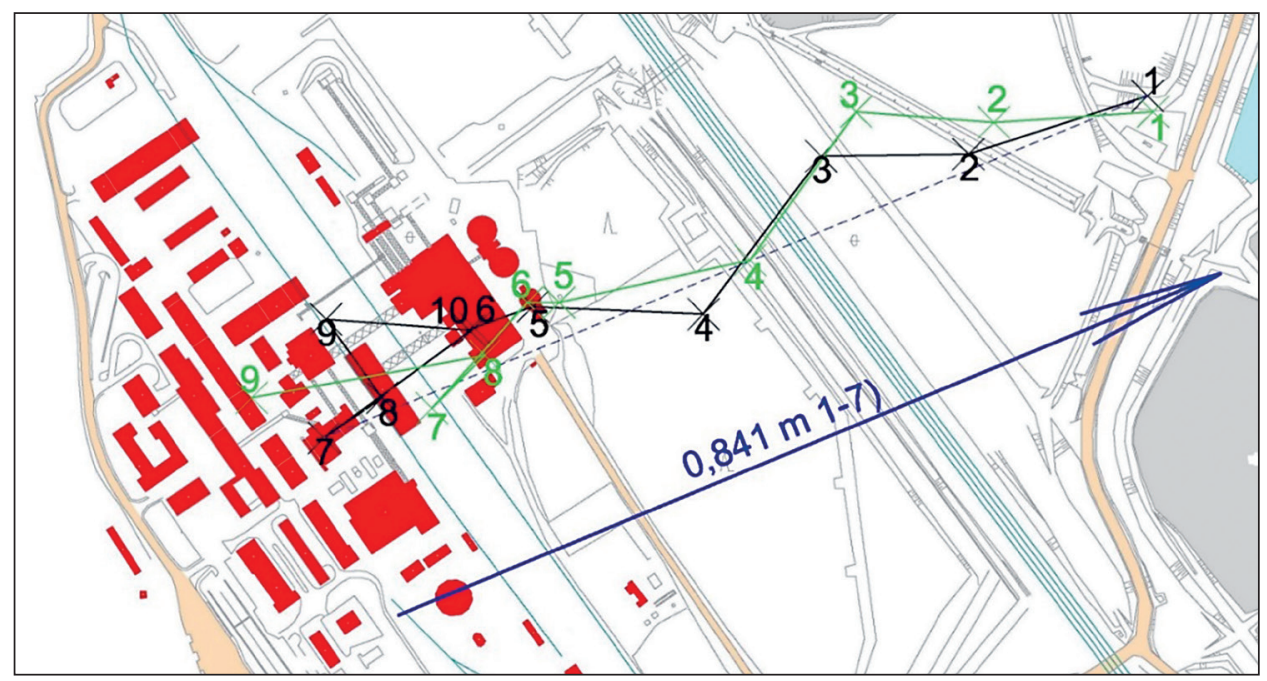

Fig. 2. Measured resultant horizontal displacements in shaft No.1 in relation to the surface ground Rys. 2. Zmierzone wypadkowe przemieszczenia poziome w szybie nr $1 \mathrm{w}$ odniesieniu do powierzchni terenu 


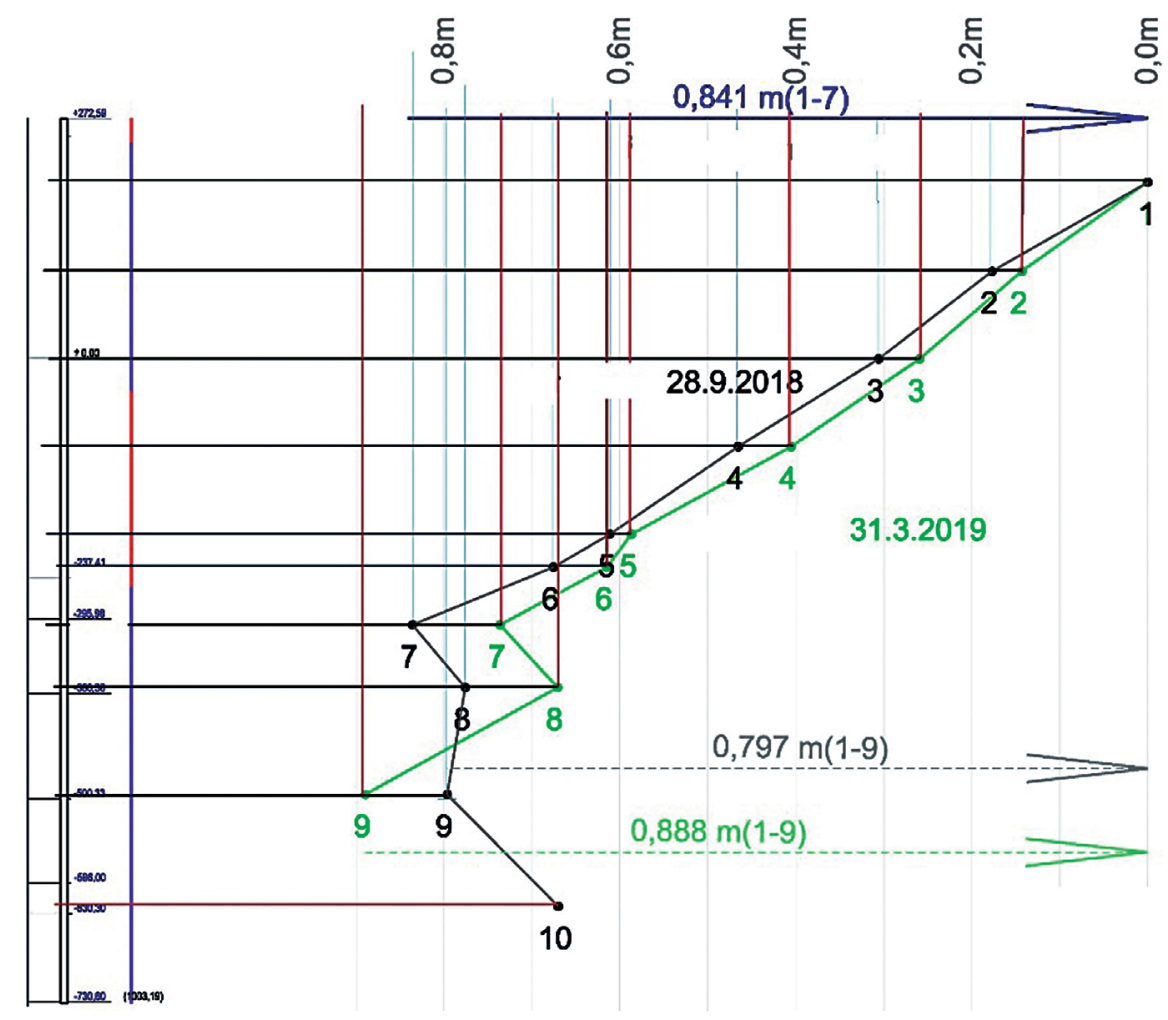

Fig. 3. Measured resultant horizontal displacements in shaft No.1

Rys. 3. Zmierzone wypadkowe przemieszczenia poziome w szybie $\mathrm{nr} 1$

The carried out reprognosis of impacts demonstrated that the completed mining resulted in the development of rock mass deformations in the area of shafts No.1 and No. 2, comprising shaft sections from the near-surface edge of shaft lining to the depth of about $600 \mathrm{~m}$.

The values of the calculated deformations at the near-surface edge of shaft lining of shaft No.1 (where maximum deformations occurred) and at the depths of $200 \mathrm{~m}$ and $400 \mathrm{~m}$ were respectively:

- subsidence - $517 \mathrm{~mm}, 152 \mathrm{~mm}$ and $18 \mathrm{~mm}$,

- final, resultant horizontal displacements $-862 \mathrm{~mm}$, $299 \mathrm{~mm}$ and $42 \mathrm{~mm}$,

- final, resultant changes of inclination $-5.38 \mathrm{~mm} /$ $\mathrm{m}, 2.18 \mathrm{~mm} / \mathrm{m}$ and $0.34 \mathrm{~mm} / \mathrm{m}$,

- main tensile horizontal strains $-8.73 \mathrm{~mm} / \mathrm{m}$, $4.12 \mathrm{~mm} / \mathrm{m}$ and $0.79 \mathrm{~mm} / \mathrm{m}$,

- compressive vertical strains - $-1.90 \mathrm{~mm} / \mathrm{m}$, $-0.94 \mathrm{~mm} / \mathrm{m}$ and $-0.19 \mathrm{~mm} / \mathrm{m}$.

The calculated deformations at the near-surface edge of shaft lining of shaft No.2 and at the depths of $200 \mathrm{~m}$ and $400 \mathrm{~m}$ were as follows:
- subsidence $-436 \mathrm{~mm}, 123 \mathrm{~mm}$ and $13 \mathrm{~mm}$,

- final, resultant horizontal displacements - 762 $\mathrm{mm}, 254 \mathrm{~mm}$ and $33 \mathrm{~mm}$,

- final, resultant changes of inclination $-4.98 \mathrm{~mm} /$ $\mathrm{m}, 1.87 \mathrm{~mm} / \mathrm{m}$ and $0.27 \mathrm{~mm} / \mathrm{m}$,

- main tensile horizontal strains $-7.93 \mathrm{~mm} / \mathrm{m}$, $3.63 \mathrm{~mm} / \mathrm{m}$ and $0.63 \mathrm{~mm} / \mathrm{m}$,

- compressive vertical strains - $-1.64 \mathrm{~mm} / \mathrm{m}$, $-0.79 \mathrm{~mm} / \mathrm{m}$ and $-0.14 \mathrm{~mm} / \mathrm{m}$.

- main tensile horizontal strains $-7.93 \mathrm{~mm} / \mathrm{m}$, $3.63 \mathrm{~mm} / \mathrm{m}$ and $0.63 \mathrm{~mm} / \mathrm{m}$,

- compressive vertical strains - $-1.64 \mathrm{~mm} / \mathrm{m}$, $-0.79 \mathrm{~mm} / \mathrm{m}$ and $-0.14 \mathrm{~mm} / \mathrm{m}$.

The calculated selected indicators of rock mass deformation at the place of shafts demonstrate that the years-long mining exploitation carried out to the boundaries of the protective pillar resulted in relatively large horizontal displacements and smaller vertical ones. Consequently, it resulted in the increase of horizontal strains of the rock mass with simultaneously smaller vertical strains and the rise of shaft deflection. 


\section{ASSESSMENT OF THE IMPACT OF COMPLETED MINING EXPLOITATION ON THE DEFLECTION OF SHAFT NO.1 IN TERMS OF CALCULATIONS AND TECHNICAL CONDITION OF THE LINING OF SHAFTS NO.1 AND NO. 2}

The current condition of the lining of shafts No. 1 and No. 2, despite relatively large calculated deformations, can be assessed as good, and the cracks observed during the visual inspection, especially in shaft No. 1, have the character of shrinkage cracks caused by binding and hardening of concrete mix (during the sinking process of the shafts), and they do not result from excessive load exerted on the lining. In the light of good technical condition of the investigated shafts and the lack of damage to their lining, it is particularly important to request for the possibility and scope involving the prospects of further mining operations within the range of its impact on the protected shafts No.1 and No. 2. The scope of further mining operations is largely dependent on the values of the deformation indicators at which the required scope of protection of the objects will be maintained.

The most important indicators that characterize the deformation of shafts comprise the following [3, 4, 9, 11]:

- vertical displacements and their derivatives:

- subsidence,

- vertical strains,

- deflections of shaft axis, resulting from the difference in subsidence on a given horizon in the shaft,

- horizontal displacements and their derivatives:

- horizontal displacements,

- deflection of shaft axis effected by horizontal displacements,

- curvature of shaft axis,

- torsion of the shaft.

The assessment involving the prospects to conduct further mining operations within the impact range on the protected shafts No.1 and No.2 was based on the fundamental assumption that the deformations acting on the shaft (on its lining) are compared with the computational strain efficiency of the shaft lining to take on a given deformation index, assuming [7]:

$$
\left|\zeta_{0}\right|>|\zeta|
$$

where:

$\zeta_{0}$ - computational efficiency to take on the deformation index by the lining,

$\zeta$ - rock mass deformation index, which defines the impact of mining operations.

Equation 1 can also be used to determine the computational strain efficiency of the lining $\zeta_{0}$ to take on the value of a given deformation index, defined by the reprognosis, allowing for the results of shaft deformation surveys.

The computational efficiency to take on the deformation index by the shaft lining can be defined as the strain efficiency of the lining within a given deformation index.

In the case of shaft tube bending (deflection of the shaft axis effected by horizontal displacements), the condition of shaft lining safety can be narrowed down to the relation [7]:

$$
R>R_{d o p}
$$

where:

$R$ - radius of curvature of the vertical axis of shaft lining effected by horizontal displacement of rock mass,

$R_{\text {dop }}$ - permissible radius of curvature of shaft axis resulting from the strain efficiency of the lining.

The permissible radius of curvature of the concrete shaft lining is [7]:

$$
R_{d o p}=\frac{R_{o} \cdot h_{o}}{\Delta Z_{z}+\frac{h_{0} \cdot \varepsilon_{0 z}}{2}}=1.36 \mathrm{~km}
$$

where:

$\Delta z_{z}$ - possible change of the height of the technological connection of the concreted sections of the lining, for the concrete lining of shafts from the 1960s, adopted at $20 \mathrm{~mm}$,

$R o$ - radius of the shaft in the interior of the lining, adopted at $\mathrm{R}_{\mathrm{O}}=3,75 \mathrm{~m}$,

$h_{0}$ - height of the concreted section of the lining $\left(h_{0}=\right.$ 4,0 m),

$\varepsilon_{0 z}$ - permissible compressive vertical strain of concrete, adopted as $1 \mathrm{~mm} / \mathrm{m}$. 


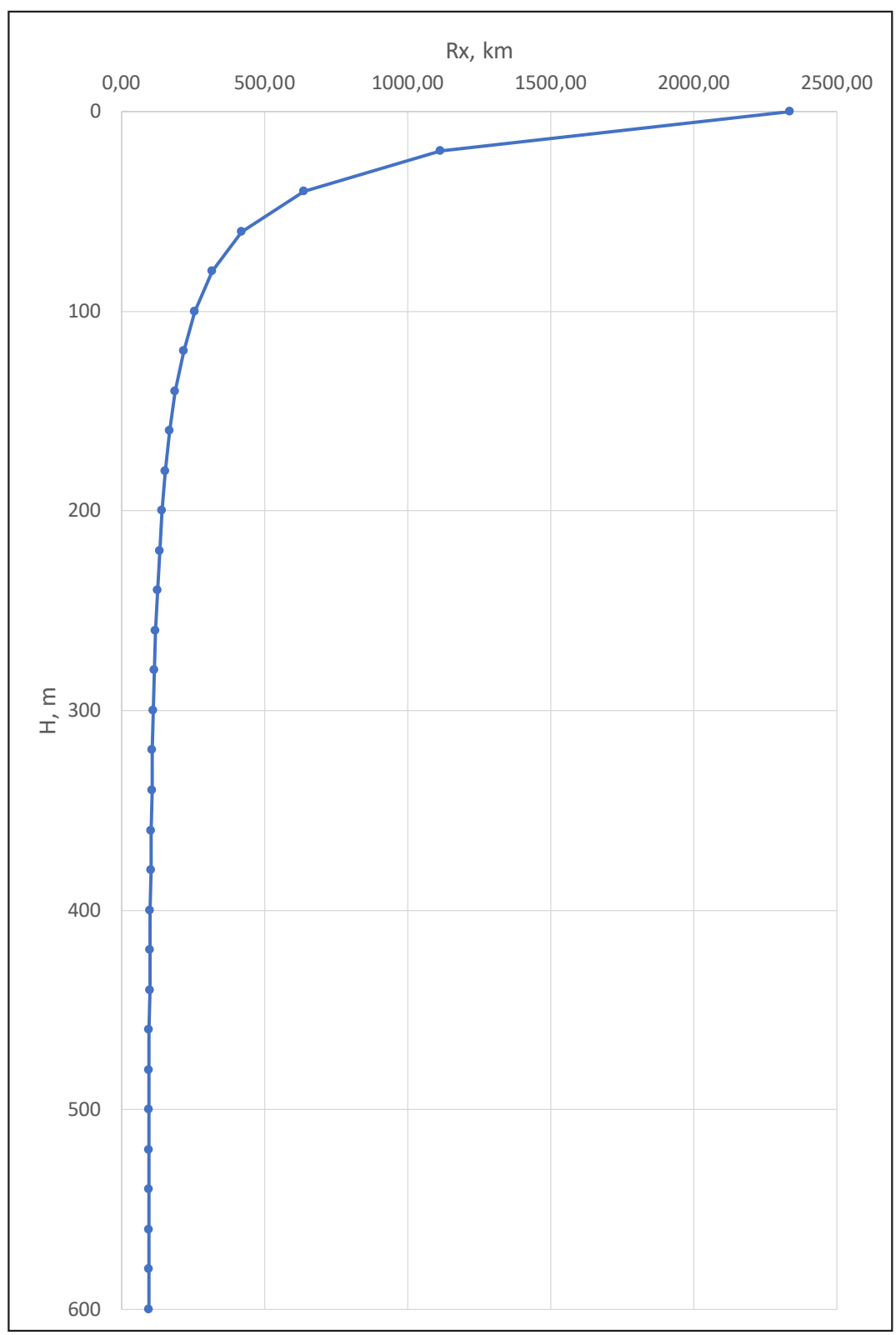

Fig. 4. Calculated distribution of radius $\mathrm{R}_{\mathrm{x}}(\mathrm{km})$ of the component of vertical axis curvature of the shaft as a function of depth $\mathrm{H}(\mathrm{m})$ in shaft No.1

Rys. 4. Obliczony rozkład promienia $R_{x}(\mathrm{~km})$ składowej krzywizny osi pionowej szybu w funkcji głębokości $H(m)$ w szybie nr 1

When the absolute value of the curvature radius of the shaft axis is higher than the permissible curvature radius of shaft lining, then it can be assumed that the shaft lining has such a strain efficiency when being bent which poses no damage risk that could threaten the stability of the lining and its safe use.

The components of the curvature radius of shaft axis projection (on the planes $\mathrm{x}, \mathrm{z}$ and $\mathrm{y}, \mathrm{z}$ ) after its deformation can be expressed by the simplified relations $[4,9]$ :

$$
\begin{aligned}
& R_{x}^{z} \approx 1 / \frac{\partial^{2} u_{x}}{\partial z^{2}} \\
& R_{y}^{z} \approx 1 / \frac{\partial^{2} u_{y}}{\partial z^{2}}
\end{aligned}
$$




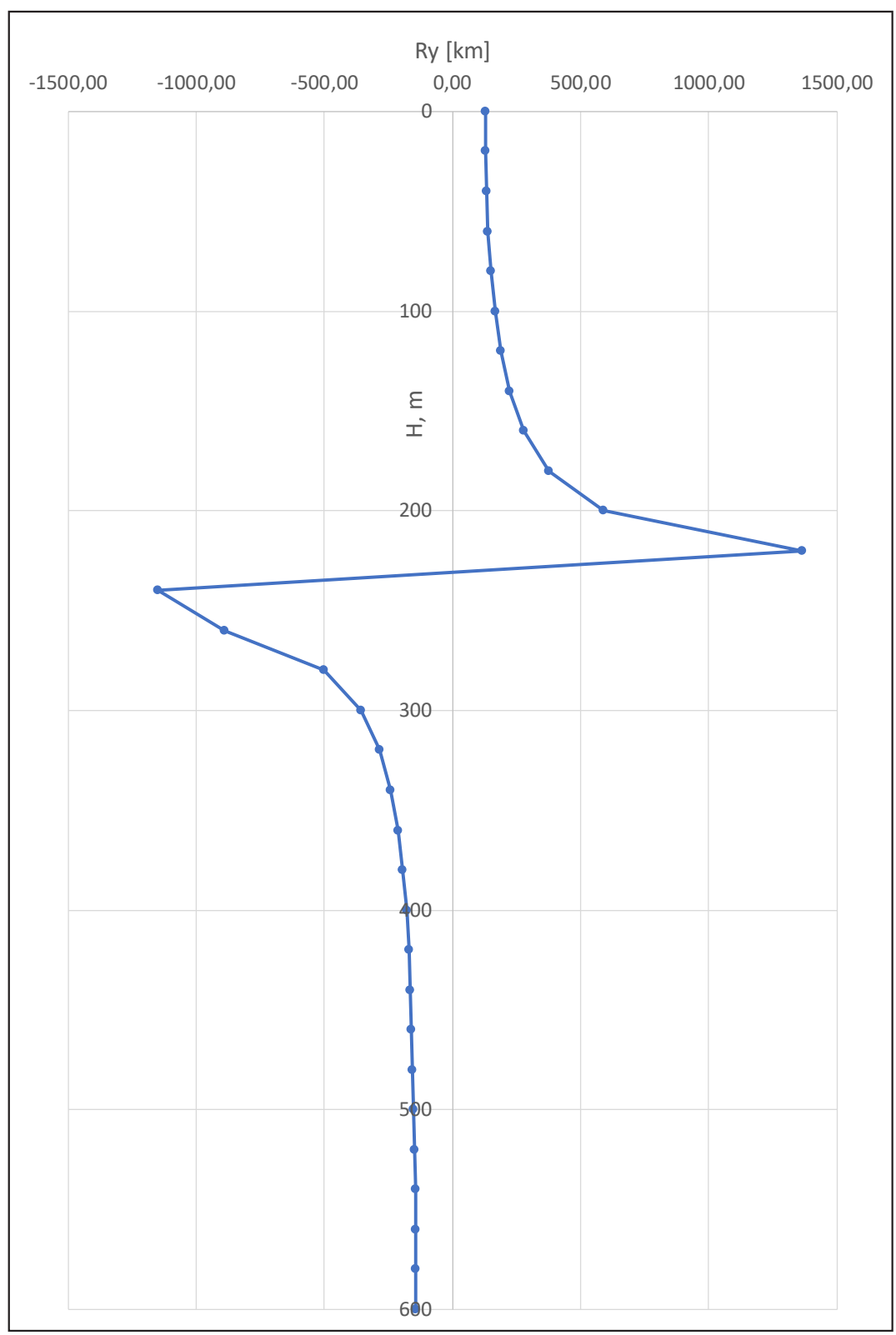

Fig. 5. Calculated distribution of radius $\mathrm{R}_{\mathrm{y}}(\mathrm{km})$ of the component of vertical axis curvature of the shaft as a function of depth $\mathrm{H}(\mathrm{m})$ in shaft No.1

Rys. 5. Obliczony rozkład promienia $R_{y}(\mathrm{~km})$ składowej krzywizny osi pionowej szybu w funkcji głębokości $H(m)$ w szybie nr 1

where:

$R_{x}^{z}, R_{y}^{z}$ - components of the curvature radius of the vertical line (shaft axis), respectively in the direction of axis $\mathrm{x}$ and axis $\mathrm{y}$,

$u_{x}, u_{x}$ - components of horizontal displacement in the direction of axes $\mathrm{x}, \mathrm{y}$,

$z \quad-$ axis directed vertically.
Basing on the reprognosis calculations involving horizontal displacements in shaft No.1, the components of the curvature of the vertical axis of shaft No. 1 were calculated based on horizontal displacements for three calculation points. Fig. 4 and Fig. 5 present the calculation results of the curvature radius of the shaft axis in the direction $\mathrm{x}$ and $\mathrm{y}$, respectively. 
We can see from the comparison of the calculated distribution of the curvature radius of shaft No.1 away effected by horizontal displacements of rock mass with the permissible curvature radius of the concrete lining of shaft No. 1 (Equation 3) that it is possible to carry out further mining operations in the area of the protective pillar. The current good technical condition of the lining of shaft No. 1 (e.g. no damage to the shaft lining which has the character of material effort) also indicates that the deflection of the shaft is lower than the permissible one.

\section{SUMMARY}

The assessment involving the prospects of mining exploitation, particularly with the disruption of protective pillar, should allow for a number of issues whereof analysis determines an informed decision-making process to conduct further mining operations which have impact on the objects protected by the pillar. The consequences of such an assessment are particularly important when the protected objects are mining shafts, which are of fundamental importance for mining operations $[5,9,12]$.

The article presents an example of such an assessment for main mineshafts together with the analysis involving the impact of completed mining operations, allowing for the technical condition of their lining.

The Coal Mine $\mathrm{X}$ in the period covering the years 1968-2018 carried out intensive mining operations altogether in 30 seams. In total, 700 longwall workings were mined out, with the mining depth ranging from $490 \mathrm{~m}$ to approx. $1180 \mathrm{~m}$.

The reprognosis calculations involving the impact of past mining operations carried out in the area of the investigated main shafts were carried out using the EDBJ software package, by determining the parameters of S. Knothe theory, by way of matching them with the results of geodetic surveys (surveys of horizontal displacements), using the method of least squares. The calculated values of deformation indicators effected by the impact of the completed years-long mining operations must be the basis for assessing the prospects to conduct planned mining operations in the protective pillar.

The results of mathematical modeling involving the impact of completed mining at the places of shafts No. 1 and No. 2 demonstrate that the shafts suffered deforma- tions comprising shaft tube sections from the near-surface edge of shaft lining to the depth of about $600 \mathrm{~m}$ (shaft No. 1) and $58 \mathrm{~m}$ (shaft No. 2). The maximum deformations occurred at the height of the near-surface edge of shaft lining, where they had the following values, respectively for shaft No.1 and shaft No. 2:

- subsidence $-517 \mathrm{~mm}$ and $436 \mathrm{~mm}$,

- final, resultant horizontal displacements - 862 $\mathrm{mm}$ and $762 \mathrm{~mm}$,

- final, resultant changes of inclination - 5.38 $\mathrm{mm} / \mathrm{m}$ and $4.98 \mathrm{~mm} / \mathrm{m}$,

- main tensile horizontal strains $-8.73 \mathrm{~mm} / \mathrm{m}$ and $7.93 \mathrm{~mm} / \mathrm{m}$,

- compressive vertical strains $--1.90 \mathrm{~mm} / \mathrm{m}$ and $-1.64 \mathrm{~mm} / \mathrm{m}$.

The above calculation results demonstrate that the dominant deformations in the said shafts are principally caused by horizontal movements of rock mass. The above account is also confirmed by the results of surveys carried out in September 2018 and March 2019, which demonstrate that the maximum horizontal displacements in shaft 1 are approx. $841 \mathrm{~mm}$.

Taking into account the current condition of the lining of main shafts and the results of the calculated past impacts of mining operations carried out together with the assessment of strain efficiency of the lining consistent with the presented methodology, we can conclude that it is possible to plan mining operations in the examined protective pillar.

\section{REFERENCES}

[1] Białek J.: Algorytmy i programy komputerowe do prognozowania deformacji terenu górniczego. Wydawnictwo Politechniki Śląskiej, Gliwice, 2003.

[2] Borecki M., Chudek M., Podgórski K., Straś J., Szczepaniak Z.: Współpraca nieupodatnionej obudowy szybu z górotworem poddanym wpływom eksploatacji górniczej. ZN Pol. Śl., s. Górnictwo z. 85, Gliwice, 1977, str. 29-36.

[3] Chudek M., Olaszowski W., Drzęźla B.: Obliczanie deformacji szybu pod wpływem eksploatacji. ZN Pol. Śl., s. Górnictwo z. 48, Gliwice, 1971, str. 123-134.

[4] Drzęźla B.: Poziome deformacje górotworu przy eksploatacji górniczej. ZN Pol. Śl., s. Górnictwo z. 44, Gliwice, 1971, str. 25-40.

[5] Hao Yan, Jixiong Zhang, Sheng Zhang, Nan Zhou: Physical modeling of the controlled shaft deformation law during the solid backfill mining of ultra-close coal seams. Bulletin of Engineering Geology and the Environment https://doi. org/10.1007/s10064-018-1335-1. 
[6] HUANG Pinglua, CHEN Congxina, XIAO Guofen: Feasibility Analysis on Using Shaft in the Region with Large Deformation. First International Symposium on Mine Safety Science and Engineering. www.sciencedirect.com Procedia Engineering 26 (2011) 1726-1730.

[7] Kleta H.: Zasady oceny bezpieczeństwa szybów i ich odporność na oddziaływania górnicze. Monografia, wyd. Politechniki Śląskiej, Gliwice, 2013.

[8] Mielimąka R.: Wpływ kolejności i kierunku eksploatacji prowadzonej frontami ścianowymi na deformacje terenu górniczego. Monografia, wyd. Politechniki Śląskiej, Gliwice, 2009.

[9] Praca zbiorowa: Ochrona powierzchni przed szkodami górniczymi. Wyd. Śląsk, Katowice, 1980.
[10] Qing Yu, Hideki Shimada, Takashi Sasaoka, Kikuo Matsui: Impact of Underground Mining on Shaft Lining and Aquifer in Eastern China. Open Journal of Geology, 2012, 2, 158-164 http://dx.doi.org/10.4236/ojg.2012.23016 Published Online July 2012.

[11] Zych J., Strzałkowski P.: Przemieszczenia i deformacje występujące w szybach pod wpływem eksploatacji górniczej. Metody i środki eksploatacji na dużych głębokościach (Wybrane zagadnienia). Wyd. Pol. Śl., Gliwice, 1987, str. 243-262.

[12] Xianzhou Lyu, Weiming Wang: Deformation Monitoring and Stability Analysis of Shaft Lining in Weakly Cemented Stratum. Advances in Civil Engineering Volume 2018, Article ID 8462746, 12 pages https://doi.org/10.1155/2018/8462746. 